\title{
A DNA barcode library for ground beetles of Germany: the genus Pterostichus Bonelli, 1810 and allied taxa (Insecta, Coleoptera, Carabidae)
}

\author{
Michael J. Raupach', Karsten Hannig², Jérome Morinière ${ }^{3}$, Lars Hendrich ${ }^{4}$ \\ I Sektion Hemiptera, Bavarian State Collection of Zoology (SNSB - ZSM), Münchhausenstraße 21, 81247 \\ München, Germany 2 Bismarckstraße 5, 45731 Waltrop, Germany 3 AIM - Advanced Identification Meth- \\ ods GmbH, Spinnereistraße 11, 04179 Leipzig 4 Sektion Insecta varia, Bavarian State Collection of Zoology \\ (SNSB - ZSM), Münchhausenstraße 21,81247 München, Germany \\ Corresponding author: Michael J. Raupach (raupach@snsb.de)
}

Academic editor: B. Guéorguiev | Received 29 June 2020 | Accepted 4 September 2020 | Published 28 October 2020

http://zoobank.org/3F8D4154-F424-4E9F-B93F-CF77FEFB6404

Citation: Raupach MJ, Hannig K, Morinière J, Hendrich L (2020) A DNA barcode library for ground beetles of Germany: the genus Pterostichus Bonelli, 1810 and allied taxa (Insecta, Coleoptera, Carabidae). ZooKeys 980: 93-117. https://doi.org/10.3897/zookeys.980.55979

\begin{abstract}
Species of the ground beetle genus Pterostichus Bonelli, 1810 are some of the most common carabids in Europe. This publication provides a first comprehensive DNA barcode library for this genus and allied taxa including Abax Bonelli, 1810, Molops Bonelli, 1810, Poecilus Bonelli, 1810, and Stomis Clairville, 1806 for Germany and Central Europe in general. DNA barcodes were analyzed from 609 individuals that represent 51 species, including sequences from previous studies as well as more than 198 newly generated sequences. The results showed a 1:1 correspondence between BIN and traditionally recognized species for 44 species (86\%), whereas two (4\%) species were characterized by two BINs. Three BINs were found for one species (2\%), while one BIN for two species was revealed for two species pairs (8\%). Low interspecific distances with maximum pairwise K2P values below $2.2 \%$ were found for four species pairs. Haplotype sharing was found for two closely related species pairs: Pterostichus adstrictus Eschscholtz, 1823/Pterostichus oblongopunctatus (Fabricius, 1787) and Pterostichus nigrita Paykull, 1790/Pterostichus rhaeticus Heer, 1837. In contrast to this, high intraspecific sequence divergences with values above $2.2 \%$
\end{abstract}

Copyright Michael J. Raupach et al. This is an open access article distributed under the terms of the Creative Commons Attribution License (CC BY 4.0), which permits unrestricted use, distribution, and reproduction in any medium, provided the original author and source are credited. 
were shown for three species (Molops piceus (Panzer, 1793), Pterostichus panzeri (Panzer, 1805), Pterostichus strenuus (Panzer, 1793)). Summarizing the results, the present DNA barcode library does not only allow the identification of most of the analyzed species, but also provides valuable information for alpha-taxonomy as well as for ecological and evolutionary research. This library represents another step in building a comprehensive DNA barcode library of ground beetles as part of modern biodiversity research.

\section{Keywords}

Abax, Central Europe, cytochrome $c$ oxidase subunit I, German Barcode of Life, mitochondrial DNA, molecular specimen identification, Molops, Poecilus, Stomis

\section{Introduction}

As part of the global International Barcode of Life initiative (IBoL; https://ibol.org), the German Barcode of Life initiative (GBoL; www.bolgermany.de) aims at capturing the genetic diversity of animals, fungi and plants of Germany using DNA barcodes in terms of modern biodiversity research (Hebert et al. 2003a, b). Despite the fact that various effects may limit the efficiency of a successful species identification, for example recent or ongoing hybridization events (e.g., Rougerie et al. 2012; Mutanen et al. 2016; Havemann et al. 2018), mitochondrial DNA-like sequences in the nucleus (numts) (e.g., Rogers and Griffiths-Jones 2012; Jordal and Kambestand 2014), or effects of Wolbachia infections (e.g., Smith et al. 2012; Klopfstein et al. 2016; Kolasa et al. 2018; Kajtoch et al. 2019), DNA barcoding has become the method of choice in terms of modern molecular species identification, including the identification of single specimens as well as metabarcoding of bulk samples (e.g., Casiraghi et al. 2010; Brandon-Mong et al. 2015). In recent years, various barcode libraries for numerous animal groups of Germany were established, including both marine and freshwater fish (Knebelsberger et al. 2014; Knebelsberger et al. 2015), amphibians and reptiles (Hawlitschek et al. 2016), echinoderms (Laakmann et al. 2017), molluscs (Gebhardt and Knebelsberger 2015; Barco et al. 2016), crustaceans (Raupach et al. 2015), spiders (Astrin et al. 2016), myriapods (Spelda et al. 2011), and numerous insect taxa, e.g., Coleoptera (Hendrich et al. 2015), Ephemeroptera, Plecoptera, Trichoptera (Morinière et al. 2017), Heteroptera (Raupach et al. 2014; Havemann et al. 2018), Hymenoptera (Schmidt et al. 2015; Schmidt et al. 2017; Schmid-Egger et al. 2019), Lepidoptera (Hausmann et al. 2011), Neuroptera (Morinière et al. 2014), and Orthoptera (Hawlitschek et al. 2017). Previous studies also laid the groundwork of a comprehensive DNA barcode library for the ground beetles (Coleoptera: Carabidae) of Germany (Raupach et al. 2010; Raupach et al. 2011; Hendrich et al. 2015; Raupach et al. 2016; Raupach et al. 2018; Raupach et al. 2019).

The Carabidae are a cosmopolitan family with an estimated number of probably more than 40,000 species world-wide (Lindroth 1986). The margined pronotum, large head, prominent mandibles, and striate elytra help to characterize this family 
(Arnett and Thomas 2000). These features, however, vary considerably throughout this taxon. Ground beetles can be found in all habitats except deserts and polar regions. Most adults of this family present a somber appearance, that is, a uniformly dark color, although some species are bi- or tricolored dorsally, and can have striking patterns (e.g., Callistus Bonelli, 1810, Omophron Latreille, 1802 or Panagaeus, Latreille, 1804). Adult ground beetles range in size from 2 up to $70 \mathrm{~mm}$ (genus Hyperion Castelnau, 1834). Most carabids are predators of invertebrates and consume many pest species, and are therefore typically considered as beneficial organisms (e.g., Lövei 1996). Within the Carabidae, the genus Pterostichus Bonelli, 1810 is a very large and diverse taxon with a Holarctic distribution, also reaching the Oriental and Neotropical regions (Hůrka 1996). More than 1,000 species are known world-wide to date, with more than 200 species are recorded for Europe (Hurrka 1996; Luff 2007) and 36 documented in Germany, including some of the commonest carabids of Germany, e.g., Pterostichus niger (Schaller, 1783), Pterostichus nigrita (Paykull, 1790), or Pterostichus strenuus (Panzer, 1796) (Trautner et al. 2014). The genus is in the present concept, however, undoubtedly not monophyletic and has been subdivided into numerous subgenera or sometimes even genera in the past (e.g., Lindroth 1986; Hůrka 1996; Luff 2007). Unfortunately, a thorough and comprehensive revision is still missing. In order to accommodate this situation, the subgeneric arrangement used in this study follows the traditional arrangement (see Marggi 2006). In general, adults of the genus Pterostichus have a body length between 5 to $25 \mathrm{~mm}$, with most species above average. They have normally a somewhat uniform appearance with a strongly sclerotized and stout pronotum, thick antennae, and rather long legs with pronounced tibiae (Lindroth 1986). The overwhelming majority of species are carnivorous, night-active black-colored insects; those with a metallic coloration are often diurnal (Lindroth 1986) (Fig. 1). Due to the fact that various species of this genus represent important and highly abundant elements of the carabid fauna of many habitats world-wide (e.g., Igondová and Majzlan 2015; Hong et al. 2017; Baranová et al. 2018), they have been intensively studied in the past, for example their general ecology (e.g., Rushton et al. 1990; Fournier and Loreau 2001; Allema et al. 2012; Brigić et al. 2014), feeding strategies (e.g., Symondson et al. 2000; Langan et al. 2001; Dinis et al. 2016), and zoogeography/phylogeography (e.g., Lagisz et al. 2010; Schmidt et al. 2012; Sasakawa et al. 2017).

In this study we present as part of the GBoL project a further step in generating a comprehensive DNA barcode library for the molecular identification of Central European ground beetle species, focusing on the genus Pterostichus and allied taxa. This barcode library included 36 species of Pterostichus as well as additional species of other genera belonging to the Pterostichini, including five species of the genus Abax Bonelli, 1810, three species of the genus Molops Bonelli, 1810, six species of the genus Poecilus Bonelli, 1810 and one species of the genus Stomis Clairville, 1806. In sum, 198 new barcodes were generated and a total number of 609 DNA barcodes examined in detail, including DNA barcodes of pinned museum specimens up to 39 years old. 

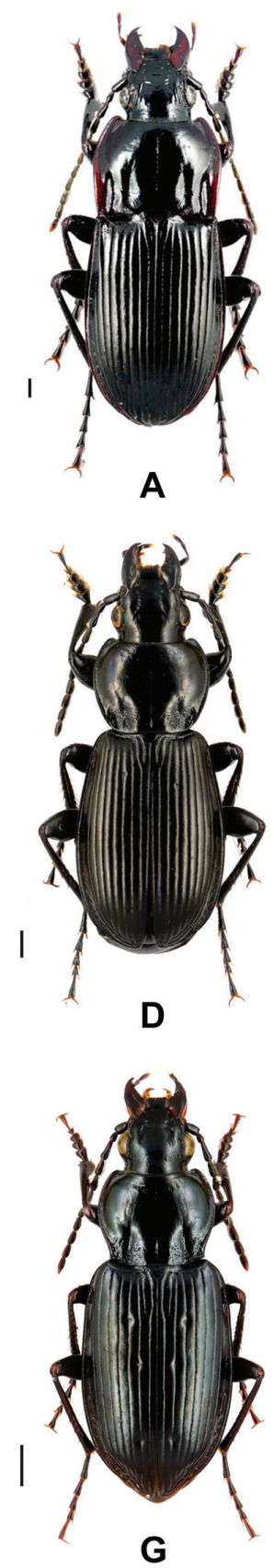
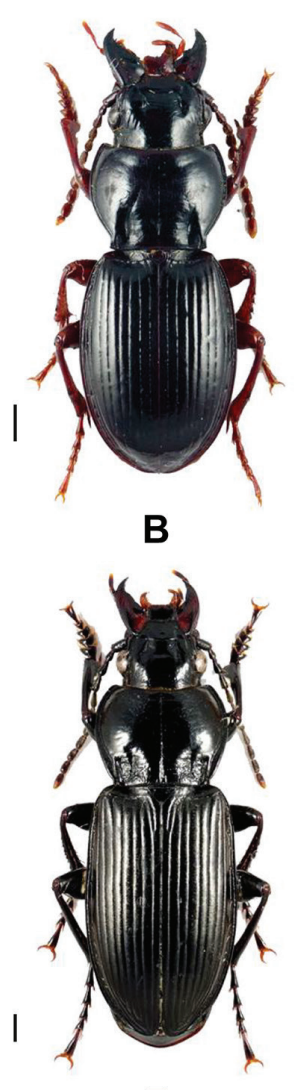

E

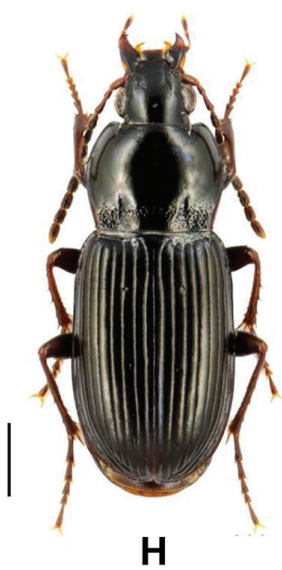

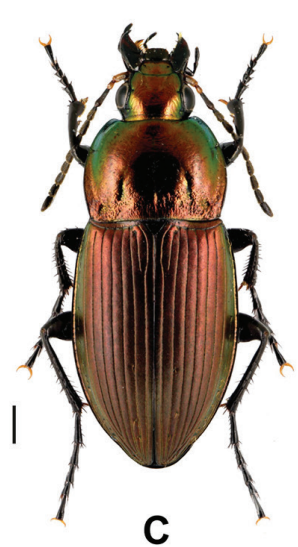
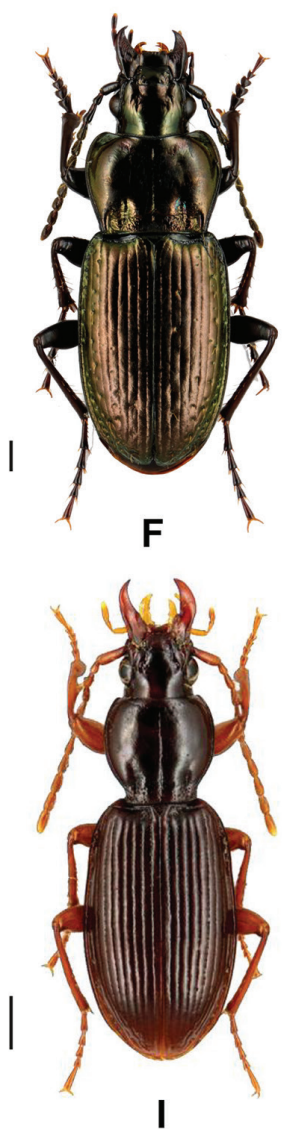

Figure I. Representative images of analyzed beetle species A Abax parallelepipedus (Piller \& Mitterbacher, 1783) B Molops piceus (Panzer, 1793) C Poecilus versicolor (Sturm, 1824) D Pterostichus (Eosteropus) aethiops (Panzer, 1796) E Pterostichus (Omaseus) melanarius (Illiger, 1798) F Pterostichus (Oreophilus) multipunctatus (Dejean, 1828) G Pterostichus (Bothriopterus) quadrifoveolatus Letzner, 1852 H Pterostichus (Argutor) vernalis Panzer, 1796 and I Stomis pumicatus (Panzer, 1795). Scale bars: $1 \mathrm{~mm}$. All images were obtained from www.eurocarabidae.de. 


\section{Materials and methods}

\section{Sampling of specimens}

Most studied ground beetles ( $\mathrm{n}=186,93.9 \%)$ were collected between 2006 and 2018 using various sampling methods (i.e., hand collecting, pitfall traps). All beetles were stored in ethanol (96\%). The analyzed specimens were identified using the identification key provided in Marggi (2006). It was also possible to generate DNA barcodes from pinned ground beetles of the carabid collection of the Bavarian State Collection of Zoology $(\mathrm{n}=12,6.1 \%)$, with an age between 22 and 39 years. In total, 198 new barcodes of 37 species were generated. Furthermore, we included 411 DNA barcodes from three previous studies (Raupach et al. 2010: 86 specimens, 16 species; Pentinsaari et al. 2014: 61 specimens, 15 species; Hendrich et al. 2015: 247 specimens, 37 species) and 17 sequences that were released without publication (7 species) in our analysis. Therefore, the complete dataset covered 609 DNA barcodes.

Most beetles were collected in Germany $(n=403,66.2 \%)$, but for comparison various specimens were included from Austria $(\mathrm{n}=82,13.5 \%)$, Belgium $(\mathrm{n}=16,2.6 \%)$, Bulgaria $(n=1,0.2 \%)$, Czech Republic $(n=4,0.7 \%)$, Estonia $(n=2,0.3 \%)$, Finland $(\mathrm{n}=59,9.7 \%)$, France $(\mathrm{n}=16,2.6 \%)$, Italy $(\mathrm{n}=10,1.6 \%)$, Romania $(\mathrm{n}=2,0.3 \%)$, Slovakia $(n=1,0.2 \%)$, Slovenia $(n=10,1.6 \%)$, and Switzerland $(n=3,0.5 \%)$. The number of analyzed specimens per species ranged from one (6 species) to a maximum of 40 for Poecilus versicolor (Sturm, 1824).

\section{DNA barcode amplification, sequencing, and data depository}

All laboratory operations were carried out, following standardized protocols for the cytochrome $c$ oxidase subunit I (COI) fragment amplification and sequencing (Ivanova et al. 2006, deWaard et al. 2008), at the Canadian Center for DNA Barcoding (CCDB), University of Guelph, the molecular labs of the Zoologisches Forschungsmuseum Alexander Koenig in Bonn, the German Centre of Marine Biodiversity Research, Senckenberg am Meer, in Wilhelmshaven, and the working group Systematics and Evolutionary Biology at the Carl von Ossietzky University Oldenburg, all in Germany. Photos from each studied beetle were taken before molecular work started. One or two legs of one body side were removed for the subsequent DNA extraction which was performed using the QIAmp Tissue Kit (Qiagen GmbH, Hilden, Germany) or NucleoSpin Tissue Kit (Macherey-Nagel, Düren, Germany), following the manufacturer's extraction protocol. The PCR temperature profile for the barcode fragment (approx. 660 base pairs) using the primer pair LCO1480 and HCO2198 (Folmer et al. 1994) consisted of an initial denaturation at $94^{\circ} \mathrm{C}(5 \mathrm{~min})$, followed by 38 cycles at $94^{\circ} \mathrm{C}$ (denaturation, $45 \mathrm{~s}$ ), $48^{\circ} \mathrm{C}$ (annealing, $45 \mathrm{~s}$ ), $72{ }^{\circ} \mathrm{C}$ (extension, $80 \mathrm{~s}$ ), and a final extension $72^{\circ} \mathrm{C}(7 \mathrm{~min})$. Purified PCR products were cycle-sequenced and sequenced in both directions at contract sequencing facilities (Macrogen, Seoul, Korea, or GATC, Konstanz, Germany), 
using the same primers as used in PCR. Double stranded sequences were assembled and checked for mitochondrial pseudogenes (numts) analyzing the presence of stop codons, frameshifts as well as double peaks in chromatograms with Geneious Prime 2020.0.4 (https://www.geneious.com) (Biomatters, Auckland, New Zealand). For verification, BLAST searches (nBLAST, search set: others, program selection: megablast) were performed to confirm the identity of all new sequences as ground beetle barcodes based on already published sequences (high identity values, very low E-values).

Comprehensive voucher information, taxonomic classifications, photos, DNA barcode sequences, primer pairs used and trace files (including their quality) are publicly accessible through the public dataset "DS-BAPTE" (Dataset ID: dx.doi.org/10.5883/ DS-BAPTE) on the Barcode of Life Data Systems (BOLD; www.boldsystems.org) (Ratnasingham and Hebert 2007). In addition, all new barcode data were deposited in GenBank (accession numbers: MN454529-MN454726).

\section{DNA barcode analysis}

The complete dataset was analyzed by using an established workflow as it was already performed in former studies (Raupach et al. 2016, Raupach et al. 2018). The analysis tools of the BOLD workbench were employed to calculate the nucleotide composition of the sequences and distributions of Kimura-2-parameter distances (K2P; Kimura 1980) within and between species (align sequences: BOLD aligner; ambiguous base/ gap handling: pairwise deletion). All barcode sequences became subject of the Barcode Index Number (BIN) analysis system implemented in BOLD that clusters DNA barcodes in order to produce operational taxonomic units that typically closely correspond to species (Ratnasingham and Hebert 2013). A first threshold of $2.2 \%$ was applied for a rough differentiation between intraspecific and interspecific distances, followed by refinements through Markov clustering into the final BINs (Ratnasingham and Hebert 2013). These BIN assignments on BOLD are constantly updated as new sequences are added, splitting and/or merging individual BINs in the light of new data (Ratnasingham and Hebert 2013).

In addition, all sequences were aligned using MUSCLE (Edgar 2004) and analyzed using a neighbor-joining cluster analysis (NJ; Saitou and Nei 1987) based on K2P distances with MEGA 10.0.5 (Kumar et al. 2018). Non-parametric bootstrap support values were obtained by resampling and analyzing 1,000 replicates (Felsenstein 1985). It should be explicitly noted that this analysis is not intended to be phylogenetic. Instead of this, the shown topology represents a graphical visualization of DNA barcode distance divergences and species clustering. For species pairs with interspecific distances $<2.2 \%$, maximum parsimony networks were constructed with TCS 1.21 based on default settings (Clement et al. 2000), implemented in the software package PopART v.1.7 (Leigh and Bryant 2015). Such networks allow the identification of possible haplotype sharing between species as a consequence of recent speciation or on-going hybridization processes. 


\section{Results}

Overall, 609 DNA barcode sequences of 51 ground beetle species of the Pterostichini were analyzed. A full list of the analyzed species is presented in the supporting information (Suppl. material 1). For the genus Pterostichus we analyzed 31 species which represent $86 \%$ of all recorded species $(n=36)$ of this genus for Germany. Beside this, the given sampling covered four species of the genus $A b a x$ (recorded species for Germany: $\mathrm{n}=4$, therefore 100\%), two species of the genus Molops $(\mathrm{n}=2,100 \%)$, six species of the genus Poecilus $(n=6,100 \%)$, and the only known species for Germany of the genus Stomis. Seven additional analyzed species are actually not recorded from Germany but included for comparison: Abax beckenhauptii (Duftschmid, 1812) $(\mathrm{n}=3)$, Molops striolatus (Fabricius, 1801) ( $\mathrm{n}=2$ ), Pterostichus adstrictus Eschscholtz, 1823 $(\mathrm{n}=5)$, Pterostichus illigeri (Panzer, 1803) $(\mathrm{n}=3)$, Pterostichus muehlfeldii (Duftschmid, 1812) $(\mathrm{n}=3)$, Pterostichus schmidtii (Chaudoir, 1838) $(\mathrm{n}=3)$, and Pterostichus ziegleri (Duftschmid, 1812) $(\mathrm{n}=8)$.

In total, fragment lengths of the analyzed DNA barcode fragments ranged from 420 to 658 base pairs. As it is typically known for arthropods, the DNA barcode region was characterized by a high AT-content: the mean sequence compositions were $\mathrm{A}=29.7 \%, \mathrm{C}=15.1 \%, \mathrm{G}=16.2 \%$, and $\mathrm{T}=39 \%$. Intraspecific K2P distances ranged from 0 to a maximum of $3.15 \%$ (Molops piceus), whereas interspecific distances within the analyzed species had values between 0 and $11.19 \%$. Lowest interspecific distances were found for Pterostichus adstrictus Eschscholtz, 1823 and Pterostichus oblongopunctatus (Fabricius, 1787) (0\%; BIN: ABY4764) as well as Pterostichus nigrita Paykull, 1790 and Pterostichus rhaeticus Heer, 1837 (0\%; BIN: AAM9738). In total, unique BINs were revealed for 44 species (86\%), two BINs for two species (4\%), three BINs for one species $(2 \%)$ and one BIN for two species for two species pairs $(8 \%)$. Due to the fact that the numbers of unspecified nucleotides ("Ns") exceeds more than $1 \%$ of their total length, a distinct cluster of two sequences for Pterostichus panzeri (Panzer, 1803) received no BIN. The NJ analyses based on K2P distances revealed non-overlapping clusters with bootstrap support values $>95 \%$ for 40 species $(78 \%)$ with more than one analyzed specimen (Fig. 2). A more detailed topology of all analyzed specimens is presented in the supporting information (Suppl. material 2).

Our statistical maximum parsimony analysis showed multiple sharing of haplotypes for Pterostichus nigrita $(\mathrm{n}=29) /$ Pterostichus rhaeticus $(\mathrm{n}=11)$ and Pterostichus adstrictus $(\mathrm{n}=5) /$ Pterostichus oblongopunctatus $(\mathrm{n}=26)$ (Fig. 3). For Pterostichus nigrita and Pterostichus rhaeticus a number of 13 different haplotypes was found (Fig. 3A) One dominant haplotype (h1) was shared by 22 specimens of Pterostichus nigrita and three specimens of Pterostichus rhaeticus (Fig. 3A). Most other haplotypes, however, were revealed only for one specimen (singletons; Pterostichus nigrita: h5-h13, Pterostichus rhaeticus: h4) and located at the tips of the network, separated from haplotype h1 or other core haplotypes (h2, h3, h10) by up to nine additional mutational steps. In case of Pterostichus adstrictus and Pterostichus oblongopunctatus, the analysis identified six haplotypes (Fig. 3B). The dominant haplotype h1 was 


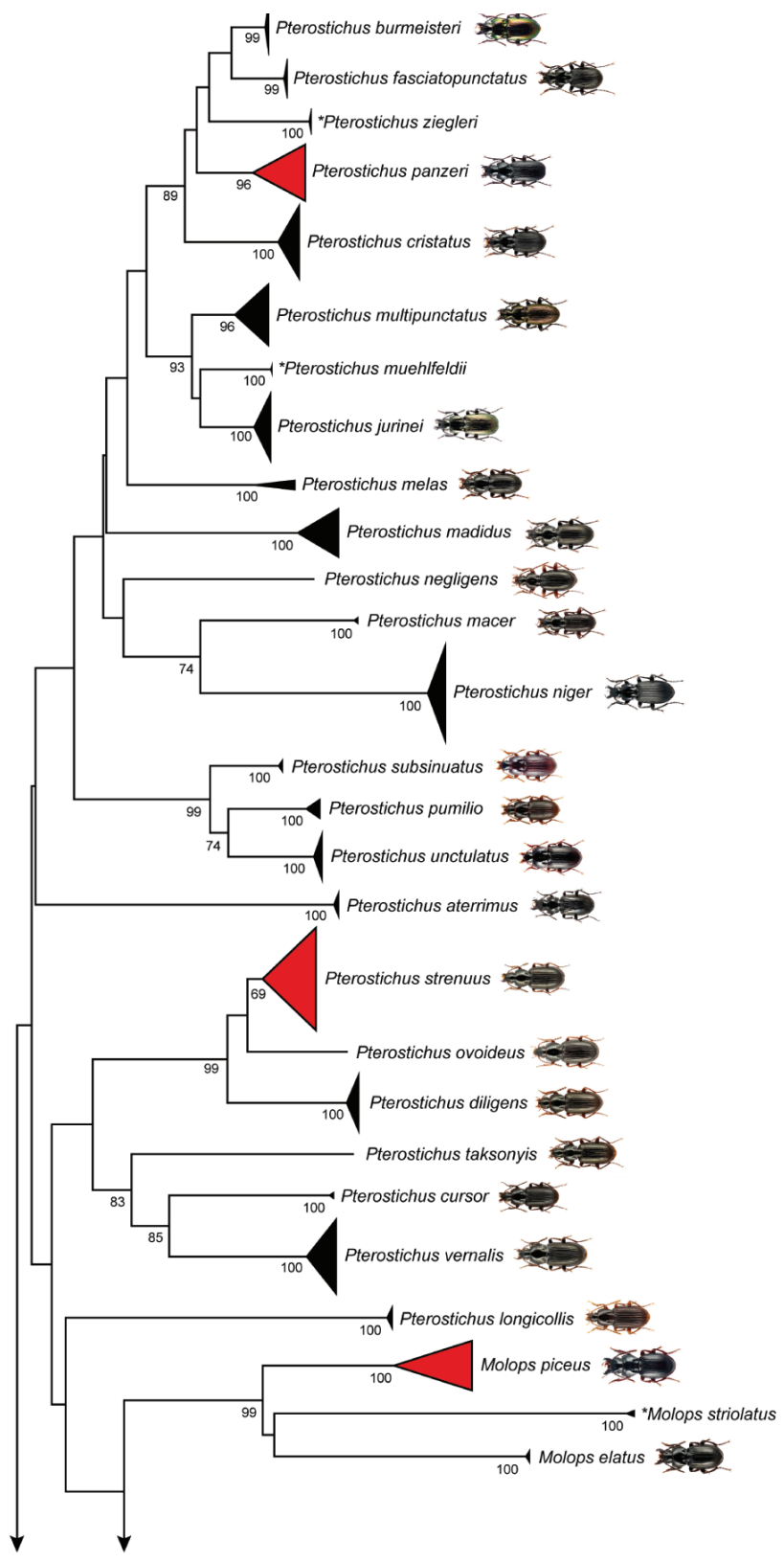

Figure 2. Neighbor-joining (NJ) topology of the analyzed ground beetle species based on Kimura 2-parameter distances. Triangles show the relative number of individual's sampled (height) and sequence divergence (width). Red triangles indicate species with intraspecific maximum pairwise distances $>2.2 \%$, blue triangles species pairs with interspecific distances $<2.2 \%$. Numbers next to nodes represent non-parametric bootstrap values $>90 \%$ (1,000 replicates). Images are provided for species recorded in Germany whereas asterisks indicate species not recorded in Germany. All beetle images were obtained from www. eurocarabidae.de except of Poecilus sericeus (photographer: Katja Neven, Lars Hendrich). 


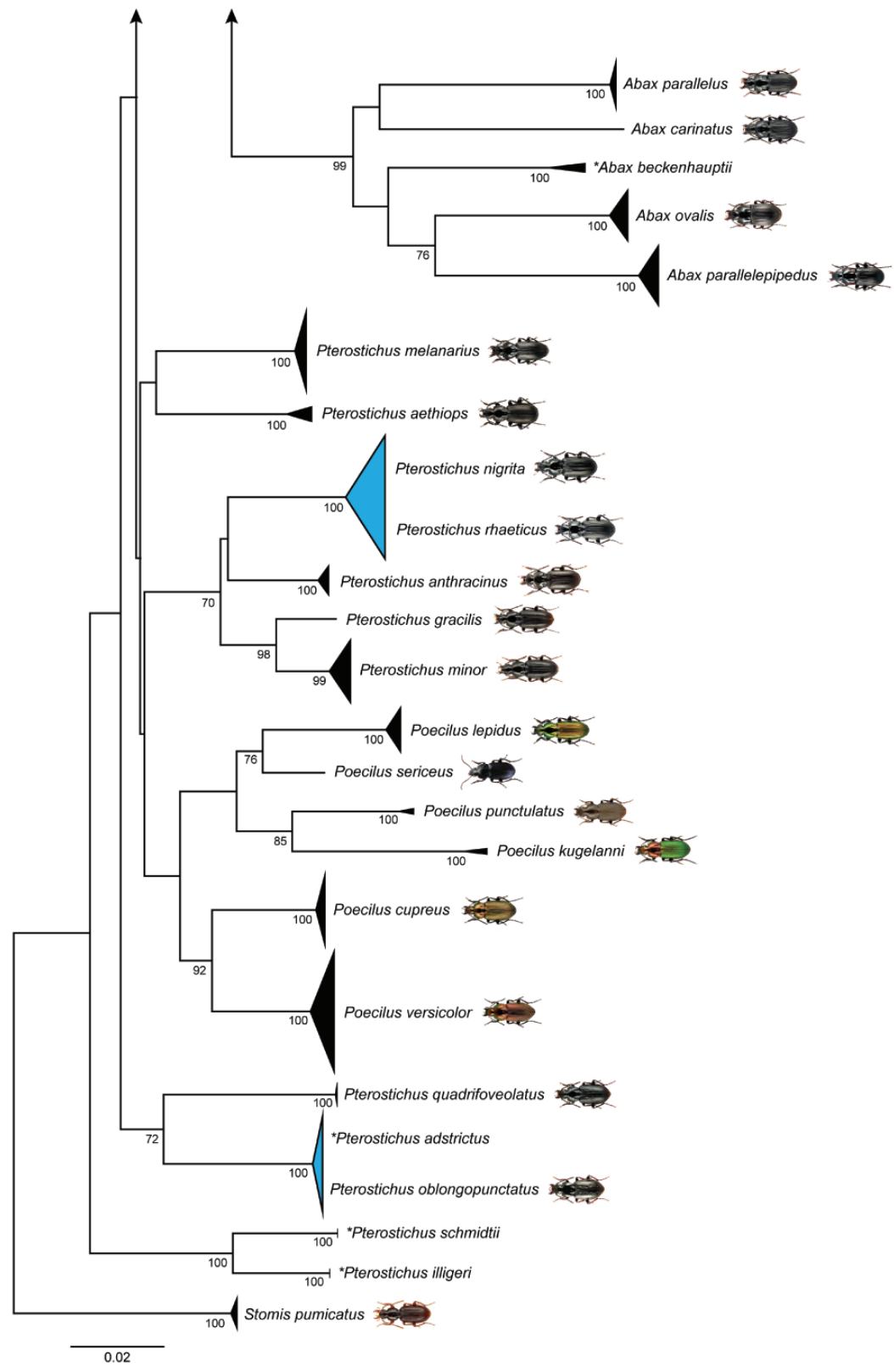

Figure 2. Continued.

shared by four specimens of Pterostichus adstrictus and 21 specimens of Pterostichus oblongopunctatus, representing the $81 \%$ of the analyzed specimens. All others were connected to this haplotype by a maximum of four mutational steps in a star-like pattern, generating a compact network. 


\section{Discussion}

As a result of preservative, passionate and intensive work in the past centuries, carabid beetles have become one of the most prominent model groups of insects for biodiversity studies (Kotze et al. 2011). Generations of carabidologists clarified most aspects of their taxonomy and phylogeny, geographic distribution, habitat associations and ecological requirements, life history strategies and adaptations, in particular for those species found in Central Europe (Kotze et al. 2011). Due to the habitat specificity of various species, ground beetles are routinely used as biological indicators to assess land use changes among different ecosystems (Lövei and Sunderland 1996; Rainio and Niemelä 2003; Pearce and Venier 2004; Koivula 2011; Kotze et al. 2011).

The present study highlights the use of DNA barcodes for the identification of species of the five genera of Pterostichini found in Germany. Unique BINs were revealed for 44 species $(86 \%)$ of the analyzed 51 taxa. This result coincides with high rates of successful species identification of previous barcoding studies in terms of carabid beetles (Raupach et al. 2010; Raupach et al. 2011; Pentinsaari et al. 2014; Hendrich et al. 2015; Raupach et al. 2018). Nevertheless, the data revealed some species pairs with low interspecific distances $(<2.2 \%)$ and shared haplotypes but also three species with intraspecific distances $>2.2 \%$.

\section{Species with low interspecific variability}

Interspecific distances with values below $2.2 \%$ were found for four ground beetle species pairs. Whereas Pterostichus burmeisteri Heer, 1838 and Pterostichus fasciatopunctatus (Creutzer, 1799) as well as Pterostichus ovoideus (Sturm, 1824) and Pterostichus strenuus (Panzer 1796) were characterized by distinct lineages, haplotype sharing was revealed for two species pairs that will be discussed more in detail in the following.

\section{The species complex Pterostichus nigrita Paykull, 1790/Pterostichus rhaeticus Heer, 1837}

Pterostichus rhaeticus and Pterostichus nigrita of the subgenus Pseudomaseus Chaudoir, 1838 are commonly considered as closely related but distinct, sibling species (Koch and Thiele 1980; Koch 1984; Müller-Motzfeld and Hartmann 1985; Koch 1986; Angus et al. 2000). Both species have a Palearctic distribution and are found in Northern and Central Europe (e.g., Hůrka 1996; Marggi 2006; Trautner et al. 2014; Muilwijk et al. 2015), but have been also recorded on the Balkan recently (Brigić et al. 2014). They differ only in a few, subtle morphological features (Koch 1984, 1986; Angus et al. 2000, 2008; Brigić et al. 2014): Specimens of Pterostichus rhaeticus are typically smaller and narrower than those of Pterostichus nigrita, but in mixed populations, the differences in body size, length and width of the elytra were not observed and the overlap in sizes is considerable (Brigić et al. 2014). Furthermore, male specimens can be differen- 
A

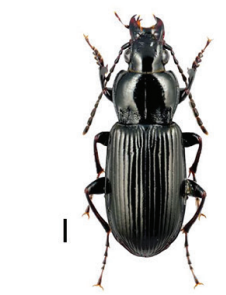

Pterostichus nigrita (Paykull, 1790)

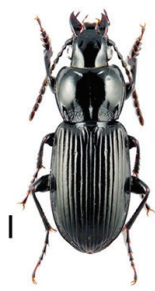

Pterostichus rhaeticus Heer, 1837 $(n=11)$

B

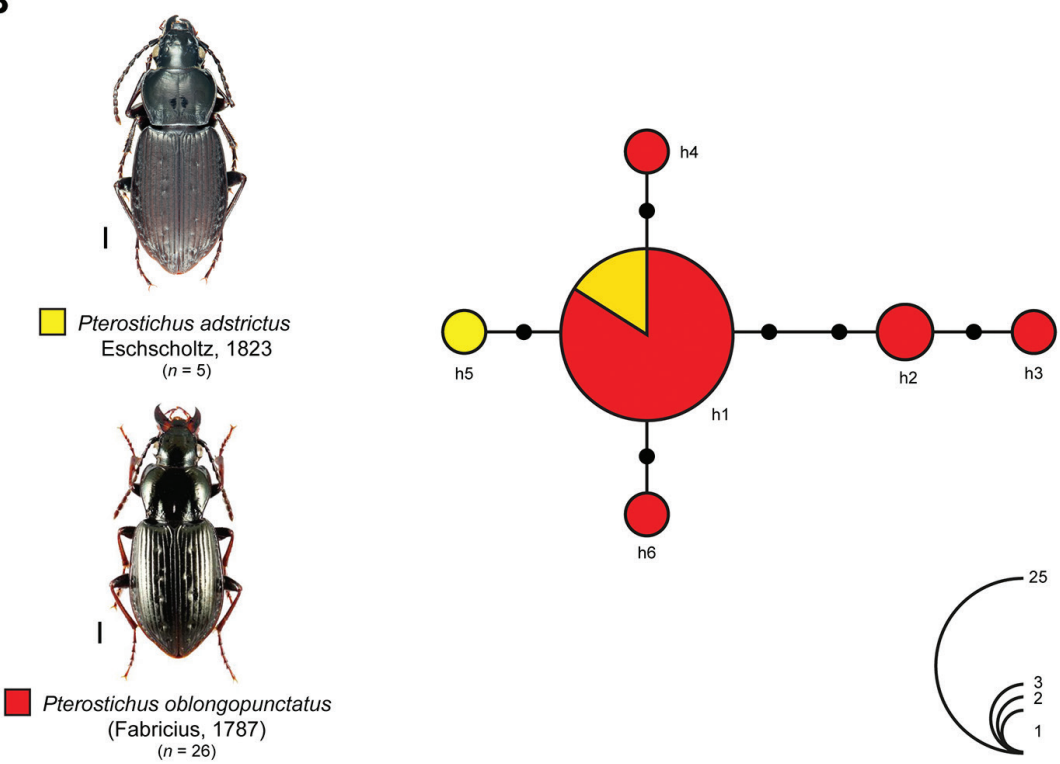

Figure 3. Maximum statistical parsimony networks of the sibling species pairs A Pterostichus nigrita Paykull, 1790 (green) and Pterostichus rhaeticus Heer, 1837 (blue) and B Pterostichus adstrictus Eschscholtz, 1823 (yellow) and Pterostichus oblongopunctatus (Fabricius, 1787) (red). Used parameters included default settings for connection steps, gaps were treated as fifth state. Each line represents a single mutational change whereas small black dots indicate missing haplotypes. The numbers of analyzed specimens $(n)$ are listed, whereas the diameter of the circles is proportional to the number of haplotypes sampled (see given open circles with numbers). Scale bars $1 \mathrm{~mm}$. Beetle images were obtained from www.eurocarabidae.de except Pterostichus adstrictus (photographer: Ditta Balke). 
tiated by the shape of the right paramere, which is larger for Pterostichus nigrita and is also characterized by a shallow incision (e.g., Hůrka 1996; Marggi 2006). In contrast to this, a deeper incision is found at the right paramere of Pterostichus rhaeticus. Nevertheless, considerable variations and intermediate forms have been documented in mixed populations of some regions and may limit the use of this character (e.g., Luff 1990; Angus et al. 2000; Brigić et al. 2014; Kendall 2017). In the case of females, both species can be distinguished by the form of the coxostylus and the shape of sclerotized part of the $8^{\text {th }}$ abdominal sternite (e.g., Koch 1986; Hůrka 1996; Angus et al. 2000). A previous study already showed that both species cannot be differentiated by the means of DNA barcodes based on shared haplotypes (Raupach et al. 2010). This result is supported by the analysis of additional data as part of this study (Fig. 3A). Various alternative hypothesis can explain these results. First, both species are distinct and do not hybridize, but lineage sorting has not been completed for the mitochondrial genome so far. Second, both species are not undergoing hybridization, but a relatively recent introgression event of the mitochondrial genome across the species boundary without concordant introgression of the nuclear genome took place. Third, extensive hybridization between both taxa is given, and these two forms might or might not be considered as different species. As consequence, additional fine scale ecological, morphological, morphometric as well as molecular data, in particular from the nuclear genome, have to be analyzed carefully to answer these questions in detail, with a focus on mixed populations from different localities.

\section{The species complex Pterostichus adstrictus Eschscholtz, 1823/Pterostichus ob- longopunctatus (Fabricius, I787)}

All DNA barcodes data of Pterostichus adstrictus $(\mathrm{n}=5)$ and some sequences of Pterostichus oblongopunctatus $(\mathrm{n}=3)$ were part of a previous study but not discussed in detail (Pentinsaari et al. 2014). Both species belong to the subgenus Bothriopterus Chaudoir, 1835 and are considered as closely related but distinct species (Lindroth 1986; Persohn 1996; Luff 2007). Whereas Pterostichus adstrictus is an inhabitant of the Northern coniferous regions (e.g., of Sweden, Norway, North America, or North Britain), Pterostichus oblongopunctatus represents a common and widely distributed Euro-Siberian species that is typically found in eurytopic woodlands (Lindroth 1986). Both species are morphological highly similar and their ranges overlap broadly in Scandinavia, but specimens of Pterostichus adstrictus can be differentiated from those of Pterostichus oblongopunctatus by unicolored, usually black legs, and the wider pronotal side border (Lindroth 1986; Persohn 1996; Luff 2007). The already hypothesized close relationship of both species is supported by haplotype sharing of DNA barcodes (see h1) (Fig. 3B). Similar to the previously discussed species pair it is unclear if both species represent closely but distinct and "valid" species or hybridization events - which have not been documented so far - still take place. 


\section{Species with high intraspecific variability}

Intraspecific pairwise distances with values $>2.2 \%$ were found for three species. Whereas Pterostichus strenuus (Panzer, 1796) showed no conspicuous substructure for the analyzed COI sequences (see Suppl. material 2), three clearly distinct monophyletic cluster/lineages were revealed within Pterostichus panzeri (Panzer, 1803) (Fig. 4, Table 1) and Molops piceus (Panzer, 1793) (Fig. 5, Table 1), respectively, and will be discussed more in detail.

\section{Ménage à trois: three distinct clusters within Pterostichus panzeri (Panzer, I803)}

The carabid Pterostichus panzeri is a subalpine/alpine brachypterous species associated with chalk and distributed in the Central European mountain regions (e.g., Horion 1941; Holdhaus 1954; Müller-Kroehling 2013; Trautner and Rietze 2017). Interestingly, all three clusters correlate with different geographic localities: cluster A included all specimens $(\mathrm{n}=8)$ from Garmisch-Partenkirchen (Germany) (BIN: ACC4332), cluster B contained only specimens from Bihor Mountains (Romania, $\mathrm{n}=2$, no BIN), and cluster $\mathrm{C}$ included beetles sampled in Austria (Totes Gebirge, $\mathrm{n}=7$, BIN: ACD0986) (Fig. 4). K2P distances between all clusters ranged from 1.4 to $2.3 \%$ (Table 1 ). Due to the fact that Pterostichus panzeri is associated to a specific habitat, it is likely that the observed genetic variability represents a result of phylogeographic effects. As a consequence of recurrent glaciation events, populations could have become isolated and gene flow disrupted, resulting in specific local haplotypes. Similar results have been found for other ground beetle species in the past (e.g., Zhang et al. 2006; Homburg et al. 2013; Faille et al. 2015). The existence of cryptic species, however, cannot be fully excluded, but no morphological variations between different populations have been reported so far. Furthermore, it should be also noted that the loss of the ability to fly can lead to a relaxed purifying selection on genes that are involved in the oxygen metabolism including COI, leading to accelerated rates of divergence in the barcode region within insects (Mitterboeck and Adamowicz 2013). The molecular analysis of additional specimens from other regions, as well as linkage groups in the nuclear genome, combined with thoroughly morphological studies will help to interpret the given results more in detail.

\section{Molops piceus austriacus Ganglbauer, I889: not a subspecies but "real” species?}

For Molops piceus, an oligophagous, brachypterous species that is found in forests, two subspecies are known: Molops piceus piceus Panzer 1793 and Molops piceus austriacus Ganglbauer, 1889. Whereas most analyzed beetles were specimens of the subspecies Molops piceus piceus $(\mathrm{n}=14)$, only one specimen of Molops piceus aus- 


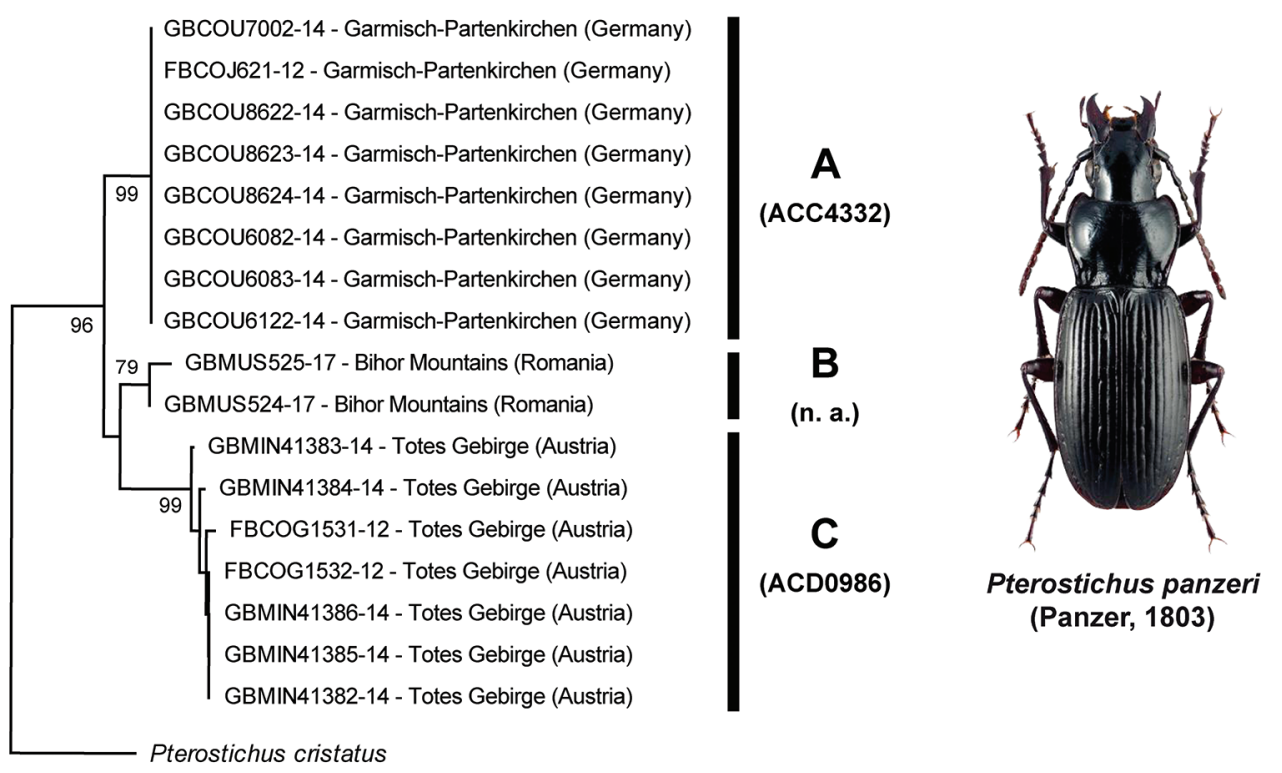

0.01 substitutions/site

Figure 4. Subtree of the Neighbor-joining topology based on Kimura 2-parameter distances of all analyzed specimens of Pterostichus panzeri (Panzer, 1805) and nearest neighbor. Branches with specimen ID-number from BOLD, species names and sample localities. Numbers next to internal nodes are nonparametric bootstrap values (in \%). Cluster (A-C) with BINs (if available) based on the barcode analysis from 11-05-2020. Beetle image was obtained from www.eurocarabidae.de.

Table I. Intraspecific Kimura 2-distances for all distinct clusters of Pterostichus panzeri (Panzer, 1805).

\begin{tabular}{l|c|c|c}
\hline & $\begin{array}{c}\text { Cluster A (Germany) } \\
\text { BIN: ACC4332 }\end{array}$ & $\begin{array}{c}\text { Cluster B (Romania) } \\
\text { BIN: n. a. }\end{array}$ & $\begin{array}{c}\text { Cluster C (Austria) } \\
\text { BIN: ACD0986 }\end{array}$ \\
\hline Cluster A (Germany) BIN: ACC4332 & 0 & & \\
\hline Cluster B (Romania) BIN: n. a. & 0.014 & 0 & \\
\hline Cluster C (Austria) BIN: ACD0986 & $0.019-0.023$ & $0.018-0.02$ & $0-0.005$ \\
\hline
\end{tabular}

triacus was studied. Nevertheless, this beetle was clearly separated from all other specimens with high K2P distance values (BIN: ADO8343) (Fig. 5, Table 2). In the past, Molops piceus austriacus has been already considered as species (Marcuzzi 1956), but only the analysis of additional specimens, additional molecular markers (e.g., hypervariable elements of the nuclear rRNA genes (Raupach et al. 2010)) and careful morphological studies will help to clarify this taxonomic problem. Furthermore, all beetles of Molops piceus piceus from Germany $(\mathrm{n}=12)(\mathrm{BIN}$ : ADO0860) were separated from one animal collected in Carinthia (Austria) (BIN: ADO8319), highlighting the necessity of additional comprehensive morphological and molecular analysis for this species. 


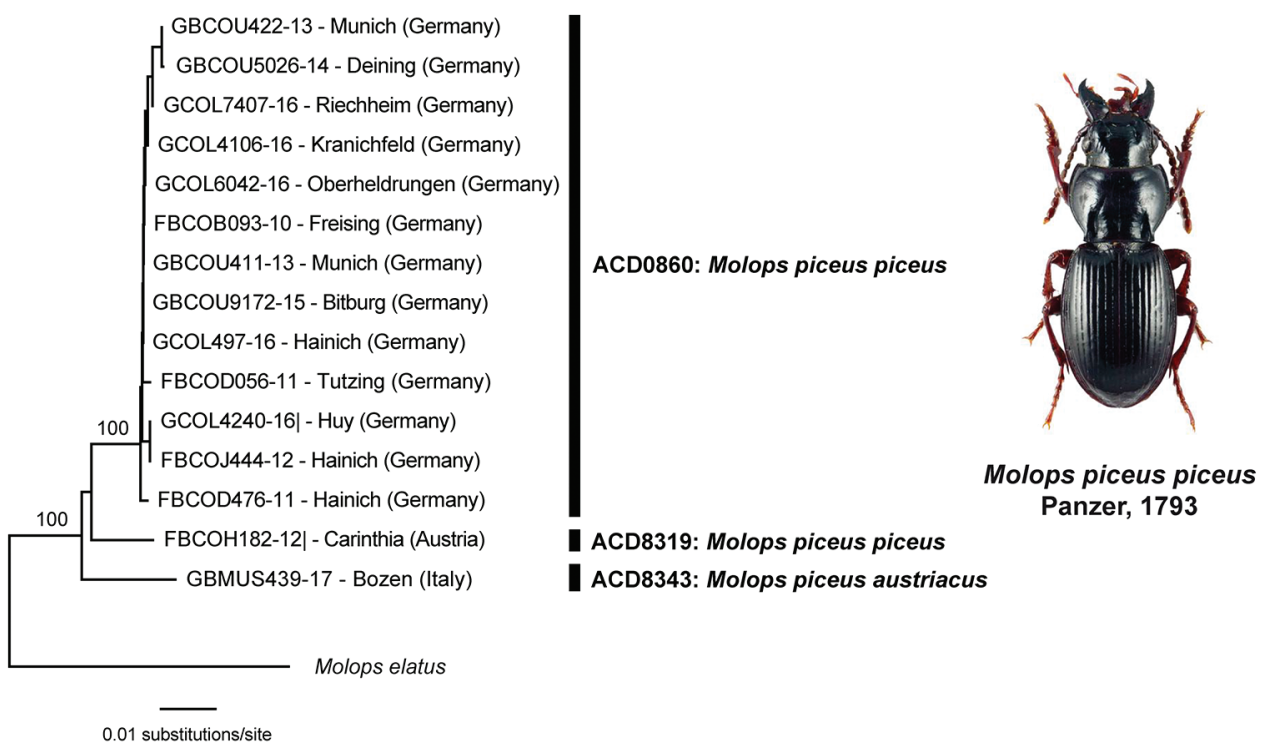

Figure 5. Subtree of the Neighbor-joining topology based on Kimura 2-parameter distances of all analyzed specimens of Molops piceus (Panzer, 1793) and nearest neighbor. Branches with specimen ID-number from BOLD, species names and sample localities. Numbers next to internal nodes are non-parametric bootstrap values (in \%). Cluster (A-C) with BINs based on the barcode analysis from 11-05-2020. Beetle image was obtained from www.eurocarabidae.de.

Table 2. Intraspecific Kimura 2-distances for all distinct clusters of Molops piceus (Panzer, 1793).

\begin{tabular}{l|c|c|c}
\hline & $\begin{array}{c}\text { M. piceus piceus (Germany) } \\
\text { BIN: ADO0860 }\end{array}$ & $\begin{array}{c}\text { M.piceus piceus (Austria) } \\
\text { BIN: ADO8319 }\end{array}$ & $\begin{array}{c}\text { M. piceus austriacus } \\
\text { (Italy) BIN: ADO8343 }\end{array}$ \\
\hline M. piceus piceus (Germany) BIN: ADO0860 & $0-0.003$ & & \\
\hline M. piceus piceus (Austria) BIN: ADO8319 & $0.019-0.028$ & 0 & \\
\hline M. piceus austriacus (Italy) BIN: ADO8343 & $0.029-0.032$ & 0.028 & 0 \\
\hline
\end{tabular}

\section{Conclusions}

The build-up of comprehensive DNA barcode libraries represents a pivotal task for modern molecular biodiversity research and species surveys (e.g., Brandon-Mong et al. 2015, Curry et al. 2018). This is especially true for the hyperdiverse and numerous species of insects. Within the beetles, carabids are highly valuable bioindicators that are used routinely to characterize disturbances in various habitats such as forests, meadows, river banks, or fens for a long time. Our DNA barcode library clearly encourages the application of DNA barcodes as effective method for the molecular identification of species of Pterostichus and allied taxa even if a few species pairs cannot be resolved. The given data, however, also revealed distinct lineages that correlate with high distances within a few species, indicating significant phylogeographic patterns and/or even the possible existence of overlooked cryptic species. 


\section{Acknowledgments}

We would like to thank Christina Blume, Claudia Etzbauer (both ZFMK, Bonn) and Jana Deppermann (DZMB, Wilhelmshaven) for their laboratory assistance. Furthermore, we are grateful to Frank Köhler (Bonn), Karl-Hinrich Kielhorn (Berlin), and Wolfgang Lorenz (Tutzing) for providing various specimens, and to Ortwin Bleich for giving permission to use his excellent photographs of ground beetles taken from www.eurocarabidae.de. We also thank David Maddison and one anonymous reviewer for their helpful comments. This publication was partially financed by German Federal Ministry for Education and Research (FKZ01LI1101A, FKZ01LI1101B, FKZ03F0664A), the Land Niedersachsen and the German Science Foundation (INST427/1-1), as well as by grants from the Bavarian State Government (Barcoding Fauna Bavarica) and the German Federal Ministry of Education and Research (GBOL1, GBOL2, GBOL3: 01LI1901B). We are grateful to the team of Paul Hebert in Guelph (Ontario, Canada) for their great support and help and in particularly to Sujeevan Ratnasingham for developing the BOLD database infrastructure and the BIN management tools. Sequencing work was partly supported by funding from the Government of Canada to Genome Canada through the Ontario Genomics Institute, whereas the Ontario Ministry of Research and Innovation and NSERC supported development of the BOLD informatics platform.

\section{References}

Allema AB, Rossing WAH, van der Werf W, Heusinkveld BG, Bukovinszky T, Steingröver E, van Lenteren JC (2012) Effect of light quality on movement of Pterostichus melanarius (Coleoptera: Carabidae). Journal of Applied Entomology 136: 793-800. https://doi. org/10.1111/j.1439-0418.2012.01728.x

Angus RB, Brown RE, Bryant LJ (2000) Chromosomes and identification of the sibling species Pterostichus nigrita (Paykull) and P. rhaeticus Heer (Coleoptera: Carabidae). Systematic Entomology 25: 325-337. https://doi.org/10.1046/j.1365-3113.2000.00108.x

Angus RB, Galián J, Wrase DW, Chaladze G (2008) The western Palaearctic species of the Pterostichus nigrita (Paykull) complex, with the description of a new species from Spain and a new subspecies of $P$. nigrita from Anatolia (Coleoptera, Carabidae). Nouvelle Revue d'Entomologie 25: 297-316.

Arnett RH, Thomas MC (2000) American Beetles, Volume 1: Archostemata, Myxophaga, Adephaga, Polyphaga: Staphyliniformia CRC Press, Boca Raton, 464 pp. https://doi. org/10.1201/9781482274325

Astrin JJ, Höfer H, Spelda J, Holstein J, Bayer S, Hendrich L, Huber BA, Kielhorn K-H, Krammer H-J, Lemke M, Monje JC, Morinière J, Rulik B, Petersen M, Janssen H, Muster C (2016) Towards a DNA barcode reference database for spiders and harvestmen of Germany. PLOS One 11: e0162624. https://doi.org/10.1371/journal.pone.0162624

Baranová B, Fazekašová D, Manko P, Jászay T (2018) Variations in Carabidae assemblages across the farmland habitats in relation to selected environmental variables including soil 
properties. Journal of Central European Agriculture 19: 1-23. https://doi.org/10.5513/ JCEA01/19.1.202

Barco A, Raupach MJ, Laakmann S, Neumann H, Knebelsberger T (2016) Identification of North Sea molluscs with DNA barcoding. Molecular Ecology Resources 16: 288-297. https://doi.org/10.1111/1755-0998.12440

Brigić A, Vujçić-Karlo S, Alegro A, Šegota V, Ternjej I (2014) Ecology, biology and conservation of Pterostichus rhaeticus Heer, 1837 (Coleoptera: Carabidae) at the edge of its distribution range, in the Western Balkans. Italian Journal of Zoology 81: 517-529. https://doi.or g/10.1080/11250003.2014.947338

Brandon-Mong GJ, Gan HM, Sing KW, Lee PS, Lim PE, Wilson JJ (2015) DNA metabarcoding of insects and allies: an evaluation of primers and pipelines. Bulletin of Entomological Research 105: 717-727. https://doi.org/0.1017/S0007485315000681

Casiraghi M, Labra M, Ferri E, Galimberti A, De Mattia F (2010) DNA barcoding: a sixquestion tour to improve users' awareness about the method. Briefings in Bioinformatics 11: 440-453. https://doi.org/10.1093/bib/bbq003

Clement M, Posada D, Crandall KA (2000) TCS: a computer program to estimate gene genealogies. Molecular Ecology 9: 1657-1660. https://doi.org/10.1046/j.1365-294x.2000.01020.x

Curry CJ, Gibson JF, Shokralla S, Hajibabaei M, Baird DJ (2018) Identifying North American freshwater invertebrates using DNA barcodes: are existing COI sequence libraries fit for purpose? Freshwater Science 37: 178-189. https://doi.org/10.1086/696613

deWaard JR, Ivanova NV, Hajibabaei M, Hebert PDN (2008) Assembling DNA barcodes: analytical protocols. In: Martin C (Ed.) Methods in Molecular Biology: Environmental Genetics. Humana Press, Totowa, 275-293. https://doi.org/10.1007/978-1-59745-548-0_15

Dinis AM, Pereira JA, Benhadi-Marin J, Santos SAP (2016) Feeding preferences and functional responses of Calathus granatensis and Pterostichus globosus (Coleoptera: Carabidae) on pupae of Bactrocera olea (Diptera: Tephritidae). Bulletin of Entomological Research 106: 701-709. https://doi.org/10.1017/S0007485316000213

Edgar RC (2004) MUSCLE: a multiple sequence alignment method with reduced time and space complexity. BMC Bioinformatics 5: 113. https://doi.org/10.1186/1471-2105-5-113 Faille A, Tänzler R, Toussaint EFA (2015) On the way to speciation: shedding light on the Karstic phylogeography of the microendemic cave beetle Aphaenops cerberus in the Pyrenees. Journal of Heredity 106: 692-699. https://doi.org/10.1093/jhered/esv078

Felsenstein J (1985) Confidence limits on phylogenies: an approach using the bootstrap. Evolution 39: 783-791. https://doi.org/10.2307/2408678

Folmer O, Black M, Hoeh W, Lutz R, Vrijenhoek R (1994) DNA primers for amplification of mitochondrial cytochrome c oxidase subunit I from diverse metazoan invertebrates. Molecular Marine Biology and Biotechnology 3: 294-299.

Fournier E, Loreau M (2001) Activity and satiation state in Pterostichus melanarius: an experiment in different agricultural habitats. Ecological Entomology 26: 235-244. https://doi. org/10.1046/j.1365-2311.2001.00314.x

Gebhardt K, Knebelsberger T (2015) Identification of cephalopod species from the North and Baltic Seas using morphology, COI and $18 \mathrm{~S}$ rDNA sequences. Helgoland Marine Research 69: 259-271. https://doi.org/10.1007/s10152-015-0434-7 
Hausmann A, Haszprunar G, Hebert PDN (2011) DNA barcoding the geometrid fauna of Bavaria (Lepidoptera): successes, surprises, and questions. PLOS One 6: e17134. https:// doi.org/10.1371/journal.pone.0017134

Havemann N, Gossner MM, Hendrich L, Morinière J, Niedringhaus R, Schäfer P, Raupach MJ (2018) From water striders to water bugs: The molecular diversity of aquatic Heteroptera (Gerromorpha, Nepomorpha) of Germany based on DNA barcodes. PeerJ 6: e4577. https://doi.org/10.7717/peerj.4577

Hawlitschek O, Morinière J, Dunz A, Franzen M, Rödder D, Glaw F, Haszprunar G (2016) Comprehensive DNA barcoding of the herpetofauna of Germany. Molecular Ecology Resources 16: 242-253. https://doi.org/10.1111/1755-0998.12416

Hawlitschek O, Morinière J, Lehmann GUC, Lehmann AW, Kropf M, Dunz A, Glaw F, Detchaeron M, Schmidt S, Hausmann A, Szucsich NU, Caetano-Wyler SA, Haszprunar G (2017) DNA barcoding of crickets, katydids and grasshoppers (Orthoptera) from Central Europe with focus on Austria, Germany and Switzerland. Molecular Ecology Resources 17: 1037-1053. https://doi.org/10.1111/1755-0998.12638

Hebert PDN, Cywinska A, Ball SL, deWaard JR (2003a) Biological identifications through DNA barcodes. Proceedings of the Royal Society of London Series B: Biological Sciences 270: 313-321. https://doi.org/10.1098/rspb.2002.2218

Hebert PDN, Ratnasingham S, deWaard JR (2003b) Barcoding animal life: cytochrome $c$ oxidase subunit 1 divergences among closely related species. Proceedings of the Royal Society of London Series B: Biological Sciences 270: S96-S99. https://doi.org/10.1098/rsbl.2003.0025

Hendrich L, Morinière J, Haszprunar G, Hebert PDN, Hausmann A, Köhler F, Balke M (2015) A comprehensive DNA barcode database for Central European beetles with a focus on Germany: Adding more than 3,500 identified species to BOLD. Molecular Ecology Resources 15: 795-818. https://doi.org/10.1111/1755-0998.12354

Holdhaus K (1954) Die Spuren der Eiszeit in der Tierwelt Europas. Abhandlungen der Zoologisch-Botanischen Gesellschaft in Wien 28: 1-606. [In German]

Homburg K, Drees C, Gossner MM, Rakosy L, Vrezec A, Assmann T (2013) Multiple glacial refugia of the low-dispersal ground beetle Carabus irregularis: molecular data support predictions of species distribution models. PLOS One 8: e61185. https://doi.org/10.1371/ journal.pone.0061185

Hong EJ, Kim Y, Jeong J-C, Kang S-H, Jung J-K, Suk S-W (2017) Community structure and distribution of ground beetles (Coleoptera: Carabidae) in Sobaeksan National Park, Korea. Journal of Ecology and Environment 41: 17 https://doi.org/10.1186/s41610-017-0036-1

Horion A (1941) Faunistik der Deutschen Käfer, Band 1, Adephaga. Goecke, Krefeld, 463 pp. [In German]

Hůrka K (1996) Carabidae of the Czech and Slovak Republics. Kabouek, Zlín, 565 pp.

Igondová E, Majzlan O (2015) Assemblages of ground beetles (Carabidae, Coleoptera) in peatland habitat, surrounding dry pine forests and meadows. Folia Oecologica 42: 21-28.

Ivanova NV, deWaard JR, Hebert PDN (2006) An inexpensive, automation-friendly protocol for recovering high-quality DNA. Molecular Ecology Notes 6: 998-1002. https://doi. org/10.1111/j.1471-8286.2006.01428.x 
Jordal BH, Kambestand M (2014) DNA barcoding of bark and ambrosia beetles reveals excessive NUMTs and consistent east-west divergence across Palearctic forests. Molecular Ecology Resources 14: 7-17. https://doi.org/10.1111/1755-0998.12150

Kajtoch Ł, Kolasa M, Kubisz D, Gutowski JM, Ścibior R, Mazur MA, Holecová (2019) Using host species traits to understand the Wolbachia infection distribution across terrestrial beetles. Scientific Reports 9: 847. https://doi.org/10.1038/s41598-018-38155-5

Kendall P (2017) The problem of two closely related ground beetles (Coleoptera: Carabidae) from Thorne Moors: Habitats and Separation of Pterostichus nigrita (Payk.) and P. rhaeticus Heer. Thorne \& Hatfield Moor Papers 10: 110-117.

Kimura M (1980) A simple method for estimating evolutionary rates of base substitutions through comparative studies of nucleotide sequences. Journal of Molecular Evolution 16: 111-120. https://doi.org/10.1007/BF01731581

Klopfstein S, Kropf C, Baur H (2016) Wolbachia endosymbionts distort DNA barcoding in the parasitoid wasp genus Diplazon (Hymenoptera: Ichneumonidae). Zoological Journal of the Linnean Society 177: 541-557. https://doi.org/10.1111/zoj.12380

Knebelsberger T, Landi M, Neumann H, Kloppmann M, Sell A, Campbell P, Laakmann S, Raupach MJ, Carvalho G, Costa FO (2014) A reliable DNA barcode reference library for the identification of the European shelf fish fauna. Molecular Ecology Resources 14: 1060-1071. https://doi.org/10.1111/1755-0998.12238

Knebelsberger T, Dunz AR, Neumann D, Geiger MF (2015) Molecular diversity of Germany`s freshwater fishes and lampreys assessed by DNA barcoding. Molecular Ecology Resources 15: 562-572. https://doi.org/10.1111/1755-0998.12322

Koch D (1984) Pterostichus nigrita, ein Komplex von Zwillingsarten. Entomologische Blätter 79: 141-151. [In German]

Koch D (1986) Morphological-physiological studies on "Pterostichus nigrita" (Col., Carab.), a complex of sibling species. In: den Boer PJ, Luff ML, Mossakowski D, Weber F (Eds) Carabid beetles, their evolution, natural history and classification. Gustav Fischer, Stuttgart/ New York, 267-279.

Koch D, Thiele HU (1980) Zur ökologisch-physiologischen Differenzierung und Speziation der Laufkäfer-Art Pterostichus nigrita (Coleoptera: Carabidae). Entomologia Generalis 6: 135-150. [In German]

Koivula MJ (2011) Useful model organisms, indicators, or both? Ground beetles (Coleoptera, Carabidae) reflecting environmental conditions. ZooKeys 100: 287-317. https://doi. org/10.3897/zookeys.100.1533

Kolasa M, Kubisz D, Mazur MA, Ścibior R, Kajtoch Ł (2018) Wolbachia prevalence and diversity in selected riverine predatory beetles (Bembidiini and Paederini). Bulletin of Insectology 71: 193-200.

Kotze DJ, Brandmayr P, Casale A, Dauffy-Richard E, Dekoninck W, Koivula MJ, Lövei GL, Mossakowski D, Noordijk J, Paarmann W, Pizzolotto R, Saska P, Schwerk A, Serrano J, Szyszko J, Taboada A, Turin H, Venn S, Vermeulen R, Zetto T (2011) Forty years of carabid beetle research in Europe - from taxonomy, biology, ecology and population studies to bioindication, habitat assessment and conservation. In: Kotze DJ, Assmann T, Noordijk J, Turin 
H, Vermeulen R (Eds) Carabid Beetles as Bioindicators: Biogeographical, Ecological and Environmental Studies. ZooKeys 100: 55-148. https://doi.org/10.3897/zookeys.100.1523 Kumar S, Stecher G, Li M, Knyaz C, Tamura K (2018) MEGA X: Molecular Evolutionary Genetics Analysis across computing platforms. Molecular Biology and Evolution 35: 15471549. https://doi.org/10.1093/molbev/msy096

Laakmann S, Boos K, Knebelsberger T, Raupach MJ, Neumann H (2017) Species identification of echinoderms from the North Sea by combining morphology and molecular data. Helgoland Marine Research 70: 18. https://doi.org/10.1186/s10152-016-0468-5

Lagisz M, Wolff K, Sanderson RA, Laskowski R (2010) Genetic population structure of the ground beetle, Pterostichus oblongopunctatus, inhabiting a fragmented and polluted landscape: Evidence for sex-biased dispersal. Journal of Insect Science 10: 105. https://doi. org/10.1673/031.010.10501

Langhan AM, Pilkington G, Wheater CP (2001) Feeding preferences of a predatory beetle (Pterostichus madidus) for slugs exposed to lethal and sub-lethal dosages of metaldehyde. Entomologia Experimentalis et Applicata 98: 245-248. https://doi.org/10.1046/j.15707458.2001.00780.x

Leigh JW, Bryant D (2015) POPART: Full-feature software for haplotype network construction. Methods in Ecology and Evolution 6: 1110-1116. https://doi.org/10.1111/2041210X. 12410

Lindroth CH (1986) The Carabidae (Coleoptera) of Fennoscandia and Denmark. Fauna Entomologica Scandinavica 15: 232-497.

Lövei GL, Sunderland KD (1996) Ecology and behavior of ground beetles (Coleoptera: Carabidae). Annual Review in Entomology 41: 231-256. https://doi.org/10.1146/annurev. en.41.010196.001311

Luff ML (1990) Pterostichus rhaeticus Heer (Col., Carabidae), a British species previously confused with P. nigrita (Paykull). Entomologist's Monthly Magazine 126: 245-249.

Luff ML (2007) The Carabidae (ground beetles) of Britain and Ireland ( $2^{\text {nd }}$ edition). Handbooks for the Identification of British Insects Vol. 4 Part 2. Field Studies Council, Shrewsbury, $247 \mathrm{pp}$.

Marcuzzi G (1956) Fauna delle Dolomiti. Memorie Classe die Scienza Mathematche e Naturali 31: 1-595. [In Italian]

Marggi W (2006) Bd. 2, Adephaga 1: Carabidae (Laufkäfer). In: Freude H, Harde KW, Lohse GA, Klausnitzer B (Eds) Die Käfer Mitteleuropas. Spektrum-Verlag, Heidelberg/Berlin, 521 pp. [In German]

Mitterboeck TF, Adamowicz SJ (2013) Flight loss linked to faster molecular evolution in insects. Proceedings of the Royal Society of London Series B - Biological Sciences 280: 20131128. https://dx.doi.org/1098/rspb.2013.1128

Morinière J, Hendrich L, Hausmann A, Hebert PDN, Haszprunar G, Gruppe A (2014) Barcoding Fauna Bavarica: 78\% of the Neuropteroida fauna barcoded! PLOS One 9: e109719. https://doi.org/10.1371/journal.pone.0109719

Morinière J, Hendrich L, Balke M, Beermann AJ, König T, Hess M, Koch S, Müller R, Leese F, Hebert PDN, Hausmann A, Schubart CD, Haszprunar G (2017) A DNA barcode library for Germany`s mayflies, stoneflies and caddisflies (Ephemeroptera, Plecoptera and Tri- 
choptera). Molecular Ecology Resources 17: 1293-1307. https://doi.org/10.1111/17550998.12683

Muilwijk J, Felix R, Dekoninck W, Bleich O (2015) De loopkevers van Nederland and België (Carabidae). Entomologische Tabellen 9: 1-215. [In Dutch]

Mutanen M, Kivelä SM, Vos RA, Doorenweerd C, Ratnasingham S, Hausmann A, Huemer P, Dincâ V, van Nieukerken EJ, Lopez-Vaamonde C, Vila R, Aarvik L, Decaëns T, Efetov KA, Hebert PDN, Johnsen A, Karsholt O, Pentinsaari M, Rougerie R, Segerer A, Tarmann G, Zahiri R Godfray HCJ (2016) Species-level para- and polyphyly in DNA barcode gene trees: Strong operational bias European Lepidoptera. Systematic Biology 65: 1024-1040. https://doi.org/10.1093/sysbio/syw044

Müller-Kröhling S (2013) Prioritäten für den Wald-Naturschutz - Die Schutzverantwortung Bayerns für die Artenvielfalt in Wäldern, am Beispiel der Laufkäfer (Coleoptera: Carabidae). Waldökologie, Landschaftsforschung und Naturschutz 13: 57-72. [In German]

Müller-Motzfeld G, Hartmann M (1985) Zur Trennung von Pterostichus rhaeticus HEER und P. nigrita PAYK. (Col., Carabidae). Entomologische Nachrichten und Berichte 29: 13-17. [In German]

Pearce JL, Venier LA (2004) The use of ground beetles (Coleoptera: Carabidae) and spiders (Araneae) as bioindicators of sustainable forest management. A review. Ecological Indicators 6: 780-793. https://doi.org/10.1016/j.ecolind.2005.03.005

Pentinsaari M, Hebert PDN, Mutanen M (2014) Barcoding beetles: a regional survey of 1872 species reveals high identification success and unusually deep interspecific divergences. PLOS One 9: e108651. https://doi.org/10.1371/journal.pone.0108651

Persohn M (1996) Pterostichus adstrictus Eschscholtz, 1823 - eine Ergänzung zur Kenntnis der mitteleuropäischen Laufkäfer-Fauna (Col., Carabidae). Entomologische Nachrichten und Berichte 40: 252. [In German]

Rainio J, Niemelä J (2003) Ground beetles (Coleoptera: Carabidae) as bioindicators. Biodiversity and Conservation 12: 487-506. https://doi.org/10.1023/A:1022412617568

Ratnasingham S, Hebert PDN (2007) BOLD: The Barcode of Life Data Systems. Molecular Ecology Notes 7: 355-364. https://doi.org/10.1111/j.1471-8286.2007.01678.x

Ratnasingham S, Hebert PDN (2013) A DNA-based registry for all animal species: the Barcode Index Number (BIN) system. PLOS One 8: e66213. https://doi.org/10.1371/journal.pone.0066213

Raupach MJ, Astrin JJ, Hannig K, Peters MK, Stoeckle MY, Wägele JW (2010) Molecular species identifications of Central European ground beetles (Coleoptera: Carabidae) using nuclear rDNA expansion segments and DNA barcodes. Frontiers in Zoology 7: 26. https:// doi.org/10.1186/1742-9994-7-26

Raupach MJ, Hannig K, Wägele JW (2011) Identification of Central European ground beetles of the genus Bembidion (Coleoptera: Carabidae) using DNA barcodes: a case study of selected species. Angewandte Carabidologie 9: 63-72.

Raupach M, Hendrich L, Küchler SM, Deister F, Morinière J, Gossner MM (2014) Buildingup of a DNA barcode library for true bugs (Insecta: Hemiptera: Heteroptera) of Germany reveals taxonomic uncertainties and surprises. PLOS One 9: e106940. https://doi. org/10.1371/journal.pone.0106940 
Raupach MJ, Barco A, Steinke D, Beermann J, Laakmann S, Mohrbeck I, Neumann H, Kihara TC, Pointner K, Radulovici A, Segelken-Voigt A, Weese C, Knebelsberger T (2015) The application of DNA barcodes for the identification of marine crustaceans from the North Sea and adjacent regions. PLOS One 10: e0139421. https://doi.org/10.1371/journal.pone. 0139421

Raupach MJ, Hannig K, Moriniére J, Hendrich L (2016) A DNA barcode library for ground beetles (Insecta: Coleoptera: Carabidae) of Germany: The genus Bembidion Latreille, 1802 and allied taxa. ZooKeys 592: 121-141. https://doi.org/10.3897/zookeys.592.8316

Raupach MJ, Hannig K, Moriniére J, Hendrich L (2018) A DNA barcode library for ground beetles of Germany: The genus Amara Bonelli, 1810 (Insecta: Coleoptera: Carabidae). ZooKeys 759: 57-80. https://doi.org/10.3897/zookeys.759.24129

Raupach MJ, Hannig K, Moriniére J, Hendrich L (2019) About Notiophilus Duméril, 1806 (Coleoptera, Carabidae): Species delineation and phylogeny using DNA barcodes. Deutsche Entomologische Zeitschrift 66: 63-73. https://doi.org/10.3897/ dez.66.34711

Rogers HH, Griffiths-Jones S (2012) Mitochondrial pseudogenes in the nuclear genomes of Drosophila. PLOS One 7: e32593. https://doi.org/10.1371/journal.pone.0032593

Rougerie R, Haxaire J, Kitching IJ, Hebert PDN (2012) DNA barcodes and morphology reveal a hybrid hawkmoth in Tahiti (Lepidoptera: Sphingidae). Invertebrate Systematics 26: 445-450. https://doi.org/10.1071/IS12029

Rushton SP, Luff ML, Eyre MD (1990) Habitat characteristics of grassland Pterostichus species (Coleoptera, Carabidae). Ecological Entomology 16: 91-104. https://doi. org/10.1111/j.1365-2311.1991.tb00196.x

Sasakawa K, Kim J-L. Kim J-K, Kubota K (2017) Morphological phylogeny and biogeography of the Pterostichus raptor species group (Coleoptera: Carabidae) of ground beetles, endemic to the Korean Peninsula and adjacent islands. Journal of Asia-Pacific Entomology 20: 7-12. https://doi.org/10.1016/j.aspen.2016.11.001

Saitou N, Nei M (1987) The neighbor-joining method: a new method for reconstructing phylogenetic trees. Molecular Biology and Evolution 4: 406-425. https://doi.org/10.1093/ oxfordjournals.molbev.a040454

Schmidt J, Opgenoorth L, Höll S, Bastrop R (2012) Into the Himalayan exile: The phylogeography of the ground beetle Ethira clade supports the Tibetan origin of forest-dwelling Himalayan species groups. PLOS One 7: e45482. https://doi.org/10.1371/journal. pone. 0045482

Schmid-Egger C, Straka J, Ljubomirov T, Blagoev GA, Morinière J, Schmidt S (2019) DNA barcodes identify 99 per cent of apoid wasp species (Hymenoptera: Ampulicidae, Crabronidae, Sphecidae) from the Western Palearctic. Molecular Ecology Resources 19: 476-484. https://doi.org/10.1111/1755-0998.12963

Schmidt S, Schmid-Egger C, Morinière J, Haszprunar G, Hebert PDN (2015) DNA barcoding largely supports 250 years of classical taxonomy: identifications for Central European bees (Hymenoptera, Apoidea partim). Molecular Ecology Resources 15: 985-1000. https://doi. org/10.1111/1755-0998.12363 
Schmidt S, Taeger A, Morinière J, Liston A, Blank SM, Kramp K, Kraus M, Schmidt O, Heibo E, Prous M, Nyman T, Malm T, Stahlhut J (2017) Identification of sawflies and horntails (Hymenoptera, "Symphyta") through DNA barcodes: successes and caveats. Molecular Ecology Resources 17: 670-685. https://doi.org/10.1111/1755-0998.12614

Smith MA, Bertrand C, Crosby K, Eveleigh ES, Fernandez-Triana J, Fisher BL, Gibbs J, Hajibabaei M, Hallwachs W, Hind K, Hrcek J, Huang D-W, Janda M, Janzen DH, Li Y, Miller SE, Packer L, Quicke D, Ratnasingham S, Rodriguez J, Rougerie R, Shaw MR, Sheffield C, Stahlhut JK, Steinke D, Whitfield J, Wood M, Zhou X (2012) Wolbachia and DNA barcoding insects: Patterns, potential, and problems. PLOS One 7: e36514. https://doi. org/10.1371/journal.pone.0036514

Spelda J, Reip HS, Oliveira-Biener U, Melzer RR (2011) Barcoding Fauna Bavarica: Myriapoda - a new contribution to DNA-based identifications of centipedes and millipedes. In: Mesibov R, Short M (Eds) Proceedings of the $15^{\text {th }}$ International Congress of Myriapodology, 18-22 July 2011, Brisbane, Australia. ZooKeys 156: 123-139. https://doi. org/10.3897/zookeys.156.2176

Symondson WOC, Glen DM, Erickson ML, Lidell JE, Langdorn CJ (2000) Do earthworms help to sustain the slug predator Pterostichus melanarius (Coleoptera: Carabidae) within crops? Investigations using monoclonal antibodies. Molecular Ecology 9: 1279-1292. https://doi.org/10.1046/j.1365-294x.2000.01006.x

Trautner J, Fritze M-A, Hannig K, Kaiser M (2014) Distribution atlas of ground beetles in Germany. Books on Demand, Norderstedt, 348 pp.

Trautner J, Rietze J (2017) Tribus Pterostichini. In: Trautner J (Ed) Die Laufkäfer BadenWürttembergs. Band 1. Ulmer, Stuttgart, 416 pp. [In German]

Zhang A-B, Kubota K, Takami Y, Kim J-L, Kim J-K, Sota T (2006) Comparative phylogeography of three Leptocarabus ground beetle species in South Korea, based on the mitochondrial COI and nuclear 28S rRNA genes. Zoological Science 23: 745-754. https://doi. org/10.2108/zsj.23.745 


\section{Supplementary material I}

\section{Barcode analysis using the BOLD workbench}

Authors: Michael J. Raupach, Karsten Hannig, Jérome Morinière, Lars Hendrich

Data type: Data table

Explanation note: Molecular distances based on the Kimura 2-parameter model of the analyzed specimens of the analyzed species of the genera Abax, Molops, Poecilus, Pterostichus, and Stomis. Divergence values were calculated for all studied sequences, using the Nearest Neighbour Summary implemented in the Barcode Gap Analysis tool provided by the Barcode of Life Data System (BOLD). Align sequencing option: BOLD aligner (amino acid based HMM), ambiguous base/gap handling: pairwise deletion. ISD = intraspecific distance. BINs are based on the barcode analysis from 11-05-2020. Asterisks indicate species not recorded from Germany. Species with intraspecific maximum pairwise distances $>2.2 \%$ and species pairs with interspecific distances $<2.2 \%$ are marked in bold. As consequence that the numbers of unspecified nucleotides ("Ns") exceeds more than $1 \%$ of their total length, a distinct cluster with two sequences for Pterostichus panzeri (Panzer, 1803) received no BIN. Country codes (alpha-2 code): $\mathrm{AT}=$ Austria, $\mathrm{BE}=$ Belgium, $\mathrm{BG}=$ Bulgaria, $\mathrm{CZ}=$ Czech Republic, EE = Estonia, FI = Finland, FR = France, DE = Germany, IT = Italy, RO $=$ Romania, $\mathrm{SK}=$ Slovakia, $\mathrm{SL}=$ Slovenia and $\mathrm{CH}=$ Switzerland.

Copyright notice: This dataset is made available under the Open Database License (http://opendatacommons.org/licenses/odbl/1.0/). The Open Database License $(\mathrm{ODbL})$ is a license agreement intended to allow users to freely share, modify, and use this Dataset while maintaining this same freedom for others, provided that the original source and author(s) are credited.

Link: https://doi.org/10.3897/zookeys.980.55979.suppl1 


\section{Supplementary material 2}

\section{Neighbor-joining topology}

Authors: Michael J. Raupach, Karsten Hannig, Jérome Morinière, Lars Hendrich

Data type: Neighbor-joining topology

Explanation note: Neighbor-joining topology of all analyzed carabid beetles based on Kimura 2-parameter distances. Specimens are classified using ID numbers from BOLD and species name. Numbers next to nodes represent non-parametric bootstrap values (1,000 replicates, in \%). Pterostichus crenatus (Duftschmid, 1812) (see five specimens from Pentinsaari et al 2014) is a junior synonym of Pterostichus vernalis (Panzer, 1795). Furthermore, a specimen of Pterostichus hagenbachii (Sturm, 1824) (see Hendrich et al. 2015) was incorrectly determined. A careful re-inspection revealed this specimen as Pterostichus cristatus (Dufour, 1820).

Copyright notice: This dataset is made available under the Open Database License (http://opendatacommons.org/licenses/odbl/1.0/). The Open Database License $(\mathrm{ODbL})$ is a license agreement intended to allow users to freely share, modify, and use this Dataset while maintaining this same freedom for others, provided that the original source and author(s) are credited.

Link: https://doi.org/10.3897/zookeys.980.55979.suppl2 